\title{
Introduction: (Re)integrating Feminist Security Studies and Global Political Economy: Continuing the Conversation through Empirical Perspectives
}

\author{
Maria Martin de Almagro, Université de Montréal \\ Caitlin Ryan, University of Groningen
}

doi:10.1017/S1743923X2000032X

Attempts to integrate feminist security studies (FSS) and feminist global political economy (GPE) were first meticulously studied in the Critical Perspectives sections of the June 2015 and December 2017 issues of this journal. Although the debate has gained presence in workshops, at international conferences, and even on dedicated websites, the diverse contributions have remained rather theoretical (e.g., Bergeron, Cohn, and Duncanson 2017; Hudson 2015). The aim of these Critical Perspectives essays is to take the integration of FSS and GPE one step further by presenting empirically grounded contributions that help us contextualize the existing theoretical debates. By focusing on postwar contexts, the pieces here take seriously the material conditions of women's empowerment from a perspective attuned to the gendered and racialized logics structuring social orders in postwar states. We believe that these are the spaces where war economies and peace economies meet and where (gendered) structural transformation of societies is possible. Like the two previous collections, we do not understand FSS and GPE as additive (Chisholm and Stachowitsch 2017). Rather, we understand them as traditions that share a common goal, namely, to undermine the racialized neoliberalism and patriarchal capitalism underpinning international intervention and postwar reconstruction projects.

Two previous collections of essays, one edited by Juanita Elias (2015) and the other by Amanda Chisholm and Saskia Stachowitsch (2017), on the (re)integration of FSS and feminist GPE were heartening. The first collection offered a series of essays on how the divide between the two

Published by Cambridge University Press 1743-923X/20 \$30.00 for The Women and Politics Research Section of the American Political Science Association.

(c) The Author(s), 2020. Published by Cambridge University Press on behalf of The Women and Politics Research Section of the American Political Science Association 
fields has evolved and how feminist scholars could - or even whether they should - overcome it. The second collection brought new voices and ideas to the table and studied how a feminist integrated approach can advance understandings of "security" and "political economy" in global governance. FSS has demonstrated that in order to study (in)security, there is a need to challenge the separations between the everyday and "high politics," between the informal and formal, between what happens at home and what happens at a peace negotiation table (Enloe 2014; Shepherd 2017). Feminist GPE has also broadened mainstream understandings of the economy and highlighted how reproductive roles normally assigned to women enable the smooth functioning of the productive global economy (Elias and Roberts 2016; True 2012).

Building from several of the perspectives and considerations raised in the two collections, this forum is born of the belief that postwar contexts should be a focal point for cooperation between feminist GPE and FSS. These are the spaces where war economies and peace economies meet and (gendered) structural transformation of societies is possible. Based on our various experiences doing field research on gender, security, and development in postwar contexts, we could clearly see that (in)security and economic opportunity are already interrelated and that the dominant models of postwar peacebuilding rarely do justice to women. Our forum contributes to discussions about how to advance feminist understandings of security and political economy through empirical analyses of postwar case studies.

Previous forums indicated several paths for thinking through the postwar relations of securities and economies. Chisholm and Stachowitsch (2017) raise the crucial question of how hierarchies between security and economics are (re)produced and maintained. These hierarchies are (re) produced in postwar contexts, such as when programs for disarmament, demobilization, and reintegration and security sector reform are treated with a different level of urgency than repairing feeder roads to markets for women traders. At the same time, the treatment of economic activity across these three postwar necessities (re)produces a hierarchy of formal economic activity over informal economic activity. We share the concerns of Chisholm and Stachowitsch that cooperation between feminist GPE and FSS is not a matter of adding economy to security studies or of seeing security as a concern for economies, but of thinking about the relations between them. The most explicit reference to the postwar context comes from Bergeron, Cohn, and Duncanson (2017), who question what alternative postwar economic models might look like. 
Agathangelou (2017) also demonstrates that centralizing race/colonialism upsets normative knowledge production around what we problematize.

\section{MAKING VISIBLE INFORMAL ECONOMIES AND COLLECTIVE RIGHTS}

The idea for the wider project we are working on (Martín de Almagro and Ryan 2019) arose out of shared frustration when we left two different panels at the International Studies Association conference and bumped into each other in the hall. We found ourselves frustrated with how many discussions of postwar economics treat gender as a sort of optional add-on. Meanwhile, discussions of postconflict gendered security dynamics often discuss economics in a very narrow way, if at all. In both cases, we think a key question appears as a sort of footnote. In June 2018, we hosted a workshop on "The Women Peace and Security Agenda (WPS) and Economic Empowerment." Over three days of invigorating conversation, we came away thinking about two interrelated issues that arise from the empirical study of women's empowerment in postwar states and that we think demonstrate the already existing integration of security and economy. The first relates to the treatment of informal economies and the second to the privileging of individual versus collective rights.

Informal rights and informal economies are often marginalized within discussions of women's postwar empowerment. In their Critical Perspectives piece, Elias and Rai (2015) ask, "Where is the genderinfused violence in any economic transformation?" Here, we use this question to consider how gender-infused violence is at the core of the negligent treatment of informal economies during post-war economic transformation. Informal economies are, for the most part, sustained by female labor and rendered invisible from formal tallies of economic activity or employment rates (Enloe 1996; Nordstrom 2010). This invisibility means that state-level planning for economic development rarely accounts for women's activities in the informal economy. Meanwhile, the "solution" to women's economic empowerment, where it does appear, reflects a privileging of formal rights without attention to how structural violence can prevent women from accessing those rights.

We think this leads to a second and related point about the neoliberal model of privileging individual rights over collective rights. This matters for how women are treated as "agents of their own empowerment" and reflects Shepherd's (2011) wider claim that women in postwar contexts 
are meant to simultaneously be victims and superhero agents of their own transformation. Importantly, we see it as simplifying the complex lived realities of people in postwar contexts, where people may rely on collective action and collective rights to enhance their material economic conditions. From this perspective, the contributions in this forum show how empirical analysis can yield new insights into gendered, racialized, and classed inequalities at the intersections of global politics and global markets.

\section{BEYOND THE FSS/FEMINIST GPE DIVIDE: THE MESSINESS OF EVERYDAY EXPERIENCES IN THE AFTERMATH OF WAR}

The contribution by Mila O'Sullivan provides insight into a case in which there are attempts to implement WPS in the midst of an active conflict. Her analysis of the Ukrainian National Action Plan demonstrates how the Ukrainian state simultaneously commits to the physical security of women affected by conflict while undermining their security through economic austerity measures. Her conclusion is that the "silencing" of the gendered economic consequences of conflict limits women's ability to participate in peace building and reconstruction in the way that WPS and the Ukrainian National Action Plan prescribe.

This reflects much of the argument of Daniela Lai, who considers the question of postconflict transitional justice in Bosnia through a critique of transitional justice models that fail to take economic injustice into account. She argues that seeing justice as a practice, not merely a legalistic approach, and considering transitional justice in relation to macroeconomic reforms is essential to ensuring that transitional justice can "redress multiple and overlapping forms of violence."

Elena Stavrevska contributes clear empirical evidence to the role of informal economies and the "messiness" of everyday lives that challenge the "neat" picture of reforms for economic restructuring. In the informal economy of the "Arizona market," women's daily-lived realities demonstrate the already-existing intersections of labor market economy, subsistence, violence, and patriarchy.

The last contribution from Maria Tanyag leaves us with unsettling yet critical questions. In the era of climate catastrophe, we need to radically challenge our tendency to examine hazards in isolation. Despite the direness of climate catastrophe, Tanyag offers hope for a radical feminist reimagining in which planetary health and women's health are linked. 
Her essential and provocative question at the end of the piece, "What vision for radical change do [the lives of people at the margins] compel us to make?," is a reminder of just what is at stake.

Focusing on empirical analysis of postwar contexts as primary sites for the rebuilding of linkages between FSS and feminist GPE, this forum contributes to the conversation started by Elias (2015) and continued by Chisholm and Stachowitsch (2017). Our aim is to demonstrate not only how necessary it is to reconstruct intellectual bridges in feminist international relations but, most importantly, to show how a failure to do so silences the everyday experiences of those we claim to center in our analysis. In addition, this forum also calls for the need to rethink the very notion of (postwar) economy and insecurity that reproduces hierarchies between and within states, between and within societies, and between individuals. Looking at the interconnections between (gendered) insecurities in and after war and postwar and reconstruction economies reveals the material consequences that make visible what is at stake.

Maria Martin de Almagro is Assistant Professor in Gender and Politics at the Université de Montréal, Canada: maria.martin.de.almagro.iniesta@ umontreal.ca; Caitlin Ryan is Assistant Professor in International Security at the University of Groningen, the Netherlands: c.m.ryan@rug.nl

\section{REFERENCES}

Agathangelou, Anna M. 2017. "From the Colonial to Feminist IR: Feminist IR Studies, the Wider FSS/GPE Research Agenda, and the Questions of Value, Valuation, Security, and Violence." Politics \& Gender 13 (4): 739-46.

Bergeron, Suzanne, Carol Cohn, and Claire Duncanson. 2017. "Rebuilding Bridges: Toward a Feminist Research Agenda for Postwar Reconstruction." Politics \& Gender $13(4): 715-21$.

Chisholm, Amanda, and Saskia Stachowitsch. 2017. "(Re)integrating Feminist Security Studies and Feminist Global Political Economy: Continuing the Conversation." Politics E Gender 13 (4): 710-15.

Elias, Juanita. 2015. "Introduction: Feminist Security Studies and Feminist Political Economy: Crossing Divides and Rebuilding Bridges." Politics E Gender 11 (2): 406-8.

Elias, Juanita, and Shirin Rai. 2015. "The Everyday Gendered Political Economy of Violence." Politics \& Gender 11 (2): 424-29.

Elias, Juanita, and Adrienne Roberts. 2016. "Feminist Global Political Economies of the Everyday: From Bananas to Bingo." Globalizations 13 (6): 787-800.

Enloe, Cynthia. 1996. "Margins, Silences and Bottom Rungs: How to Overcome the Underestimation of Power in the Study of International Relations." In International Theory: Positivism and Beyond, eds. Steve Smith, Ken Booth, and Marysia Zalewski. Cambridge: Cambridge University Press, 186-202. 
2014. Bananas, Beaches and Bases: Making Feminist Sense of International Politics. San Francisco: University of California Press.

Hudson, Heidi. 2015. "(Re)framing the Relationship between Discourse and Materiality in Feminist Security Studies and Feminist IPE.” Politics \& Gender 11 (2): 413-19.

Martin de Almagro, Maria, and Caitlin Ryan. 2019. "Subverting Economic Empowerment: Towards a Postcolonial-Feminist Framework on Gender (In)Securities in Post-War Settings." European Journal of International Relations 25 (4): 1059-79.

Nordstrom, Carolyn. 2010. "Women, Economy, War." International Review of the Red Cross 92 (877): 161-76.

Shepherd, Laura J. 2011. "Sex, Security and Superhero(in)es: From 1325 to 1820 and Beyond." International Feminist Journal of Politics 13 (4): 504-21.

- 2017. Gender, UN Peacebuilding, and the Politics of Space: Locating Legitimacy. Oxford: Oxford University Press.

True, Jacqui. 2012. The Political Economy of Violence against Women. Oxford: Oxford University Press. 